\title{
ПОЛИМИНЕРАЛЫН РОST IR-IR БОЛОН КВАРЦЫН КРИСТАЛЛЫН ЛЮМИНЕСЦЕНЦИЙН АРГЫГ ХОСЛУУЛАН ОЛДВОРЫН ОН ЦАГИЙГ ТОГТООХ НЬ
}

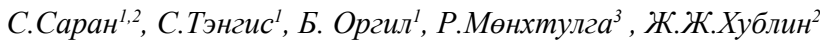 \\ ${ }^{1}$ ШУА-ийн Физик-Технологийн ХУрээлэн, Энхтайвны өргөн чөлөө 546 \\ ${ }^{2}$ Max-Planck-Institute for evolutionary anthropology, Leipzig, Germany \\ ${ }^{3}$ ШУА-ийн Археологийн Хүрээлэн, Жуковын гудамж 77
}

\begin{abstract}
Given the need to date the series of unknown burials at the site Khutag Uul, Arkhangai province (Mongolia), different luminescence dating methods were applied: p-IRIR (IR at lower temperature and post infrared stimulation at an elevated temperature) and SGL (single grain luminescence) on both heated ceramics consisting of fine grains of quartz and feldspar and unheated coarse quartz from surrounding sediments. Detailed study has been done in order to analyze the composition of the IR and p-IRIR decay curves which suggest that the equivalent doses obtained from the IR50 and IR at elevated temperature might originate from one trap. Experimental results of IR, p-IRIR suggest a date $3 \pm 75 \mathrm{BC}$ and $203 \pm 95 \mathrm{BC}$, respectively; the single grain (SG) luminescence measurements yield a date $198 \pm 94 \mathrm{BC}$ for the production of pottery. The surrounding sediment material, which was originally used for the determination of the doserate, was an mixed population with an indication that a grave was robbed around 588 $\pm 70 \mathrm{AD}$.
\end{abstract}

\section{ОРШИЛ}

Кварц $\left(\mathrm{SiO}_{2}\right)$, жонш $\left(\mathrm{KAlSi}_{3} \mathrm{O}_{8}\right)$ г.м. эрдсийнкристаллдахьметастабильдефектнь

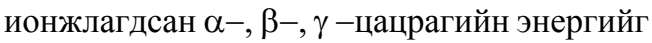
удаан хугацаагар хадгалах чадвартайд тулгуурлан эрдэст хуримтлагдсан цацрагийн тунг люминесценцийн аргаар тогтоох боломжтой. Цацраг нь орчны ${ }^{238} \mathrm{U},{ }^{232} \mathrm{Th},{ }^{40} \mathrm{~K}-$ ийн задралаас улбаатай ба энэхүҮ энерги нь фото үйлчлэлийн эсвэл дулааны өдөөлтөөр гэрлийн эмисси болж хувирдаг. Энэ гэрлийг люминесценци гэж нэрлэдэг (Aitken, 1998) ба минерал дахь люминесценцийн сигналын эрчим нь хуримтлагдсан тун $D_{e}-$ тэй эерэг коррелацитай. Орчноос нэвтрэх жилийн дундаж доз $D_{r}$-г гаммаспектрометри болон нейтрон активацийн аргаар тогтоож чадвал, $D_{e} / D_{r}$-ийн харьцаанаас минералд тун хуримтлагдсан хугацааг тогтоож болдог. Ийнхүүуг эрдэс минералыг өөртөө агуулсан шавар вааран эдлэлийг хэзээ үйлдвэрлэсэн, эсвэл хөрсний үе давхрага бий болсон он цагийг тогтоох боломжтой.

Өндөр температурт шатааж үйлдвэрлэсэн барилгын материал, шавар вааран эдлэл (Bailiff, 2007), (Solongo, 2006), огт шатаагаагүй материал: барилгын шавардлага (Bǿtter-Jensen L., 2000) г.м. материалыг үйлдвэрлэсэн он цаг хронологийн судалгааг явуулахад уг материалд агуулагдах эрдэст хуримтлагдсан цацрагийн тун $D_{e}$-г $1 \div 2 \%$-ийн алдаатай тооцоохыг эрмэлздэг. Судалгааны материалын найрлагаас улбаалан

- $\quad 212 \div 250$ мкм-ийн кварц $\left(\mathrm{SiO}_{2}\right)$ мөхлөгт кристаллын люминесценци (Single grain method) буюу ногоон лазерын өдөөлтийн люминесценцийн арга

- $90 \div 180$ мкм-ийн кварц $\left(\mathrm{SiO}_{2}\right)$ ын хөх гэрлийн люминесценци буюу OSL (blue optically stimulated luminescence), калийн жонш ( $\left.\mathrm{KAl}_{2} \mathrm{Si}_{3} \mathrm{O}_{8}\right)$-ийн хэт улаан гэрлийн люминесценци буюу IRSL (infrared stimulated luminescence)

- $4 \div 11$ мкм - ийн кварц $\left(\mathrm{SiO}_{2}\right)$, калийн жонш ( $\left.\mathrm{KAl}_{2} \mathrm{Si}_{3} \mathrm{O}_{8}\right)$ (Krbetschek M.R., 1997), альбит ( $\mathrm{Na}\left[\mathrm{AlSi}_{2} \mathrm{O}_{8}\right]$ ), анортит $\left(\mathrm{CaAl}_{2} \mathrm{Si}_{2} \mathrm{O}_{8}\right)$ г.м. минералаас бүрдэх 
полиминералын post-IR OSL (Saran Solongo et al., 2013), pIR-IR(J.P.Buylaert, 2012) г.м. өдөөлтийн люминесценцийн хэмжилтийг явуулах шаардлагатай болдог.

Энэхүү ажилд төрөл бүрийн материалд хуримтлагдсан цацрагийн тунг өндөр нарийвч-лалтай тодорхойлох хоёр аргыг хослуулан хэрэглэхийн зэрэгцээ олдворын эргэн тойронд буй хөрсөнд нэвтчих гамма цацрагийн нөлөөг судалж олдвор болон орчны хөрсний харьцуулсан цогц судалгааг явуулснаар нэн шинэлэг болов.

\section{СУДАЛГААНЫ МАТЕРИАЛ}

Архангай аймгийн Хашаат сумын Хутаг Уул (N47036'21.0”; E102047'04.7”; д.т.дээш $1508 \pm 4 \mathrm{M}$ өндөр) газарт ШУАийн Археологийн Хүрээлэнгийн авсан судалгааны дээжийг (Хүснэгт 1) люминесценцийн он цаг тогтоох болон бусад археометрийн аргаар судалгаанд экспедицийн 2009 онд хийсэн малтлагаар хамруулав.

Судалгаань материальн тойм

\begin{tabular}{|c|c|c|c|c|c|c|c|}
\hline \multirow{2}{*}{ Дээж } & \multirow{2}{*}{$\begin{array}{c}\text { Эрдэс/ арга } \\
\text { зүй }\end{array}$} & \multicolumn{3}{|c|}{$D r_{i}(m G y / a)$} & \multicolumn{2}{|c|}{$D r_{e}(m G y / a)$} & \multirow{2}{*}{$\begin{array}{c}\text { Тун хуримт- } \\
\text { лагдах хурд } \\
\text { Dr (mGy/a) }\end{array}$} \\
\hline & & $\beta^{\mathrm{a}}$ & $\boldsymbol{\beta}^{\mathrm{b}, \mathrm{c}}$ & $\alpha^{b}$ & $\gamma^{\mathfrak{c}, \mathrm{d}}$ & $\begin{array}{l}\text { Санс- } \\
\text { рын }\end{array}$ & \\
\hline \multirow{2}{*}{$\begin{array}{l}\text { L-EVA- } \\
1201, \\
\text { Baap }\end{array}$} & $\begin{array}{l}4 \div 11 \text { мкм / } \\
\text { Post IR-IR }\end{array}$ & $3.06 \pm 0.076$ & $2.754 \pm 0.102$ & $0.759 \pm 0.102$ & $\begin{array}{c}1.378 \pm \\
0.057\end{array}$ & $\begin{array}{c}0.228 \pm \\
0.019\end{array}$ & $5.090 \pm 0.170$ \\
\hline & $\begin{array}{c}212 \div 250 \text { мкм } \\
\text { кварц / SG }\end{array}$ & $2.90 \pm 0.069$ & $2.521 \pm 0.036$ & - & \multicolumn{2}{|c|}{$1.390 \pm 0.0228$} & $4.269 \pm 0.0536$ \\
\hline \multirow{2}{*}{$\begin{array}{c}\text { L-EVA- } \\
1202 \text {, } \\
\text { орчны } \\
\text { хөрс }\end{array}$} & $\begin{array}{l}4 \div 11 \text { мкм / } \\
\text { Post IR-IR }\end{array}$ & $3.22 \pm 0.040$ & $2.505 \pm 0.123$ & $0.637 \pm 0.086$ & \multicolumn{2}{|c|}{$1.403 \pm 0.0460$} & $4.481 \pm 0.179$ \\
\hline & $\begin{array}{c}212 \div 250 \text { мкм } \\
\text { кварц / SG }\end{array}$ & $2.90 \pm 0.036$ & $2.521 \pm 0.0364$ & - & \multicolumn{2}{|c|}{$1.390 \pm 0.0228$} & $4.02 \pm 0.19$ \\
\hline $\begin{array}{c}\text { L-EVA- } \\
1203 \text {, } \\
\text { хөрс }\end{array}$ & $\begin{array}{c}212 \div 250 \text { мкм } \\
\text { кварц / SG }\end{array}$ & $2.81 \pm 0.090$ & & & \multicolumn{2}{|c|}{$1.4 \pm 0.046$} & $4.21 \pm 0.18$ \\
\hline $\begin{array}{l}\text { L-EVA- } \\
\text { 1204, } \\
\text { хөрс }\end{array}$ & $\begin{array}{c}212 \div 250 \text { мкм } \\
\text { кварц / SG }\end{array}$ & $3.18 \pm 0.090$ & & & & & \\
\hline
\end{tabular}

${ }^{a}$ Бета тоолуурын хэмжилт, Лейпизицйн МПИ-д Risø GM-25-5 Beta-Counter MPI, Leipzig.

${ }^{b}$ Нейтрон активацийн аргаар хийсэн хэмжилтийн $ү р$ дүн (NAA, CEZA Mannheim).

${ }^{c} Ө$

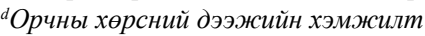

ePrescott and Hutton (1994) нарын арга зүйн дагуу тооияоосон

Дээжийн найрлагыг тогтоох зорилгоор ШУА-ийн Аналитикийн лаборатори дахь нунтгийн рентген дифрактометр Shimadzu Maxima-X, XRD-7000 дээр $\mathrm{CuK}_{\alpha}$ анодын тусламжтай, 0.6сек алхам бүрт байхаар болон сарнилын өнцгийн $5^{0} \div 80^{0}$ мужид $0.020^{\circ}$ өнцөг алхамтайгаар хэмжсэн болно.
LEVA1204 дээжүудийн туршлагаaр хэмжсэн рентген дифракцийн спектрүүдийг харьцуулан 1-р зурагт харуулав. Кварц $\left(\mathrm{SiO}_{2}\right)$, калийн жонш $\left(\mathrm{KAlSi}_{3} \mathrm{O}_{8}\right)$, албит $\left(\mathrm{NaAlSi}{ }_{3} \mathrm{O}_{8}\right)$ давамгайлж мусковит, калк $\mathrm{Ca}(\mathrm{Mn}, \mathrm{Mg})\left(\mathrm{CO}_{3}\right)_{2}$ илэрч буйг хүснэгт 2-т харуулав.

\section{LEVA1201, LEVA1202, LEVA1203,}




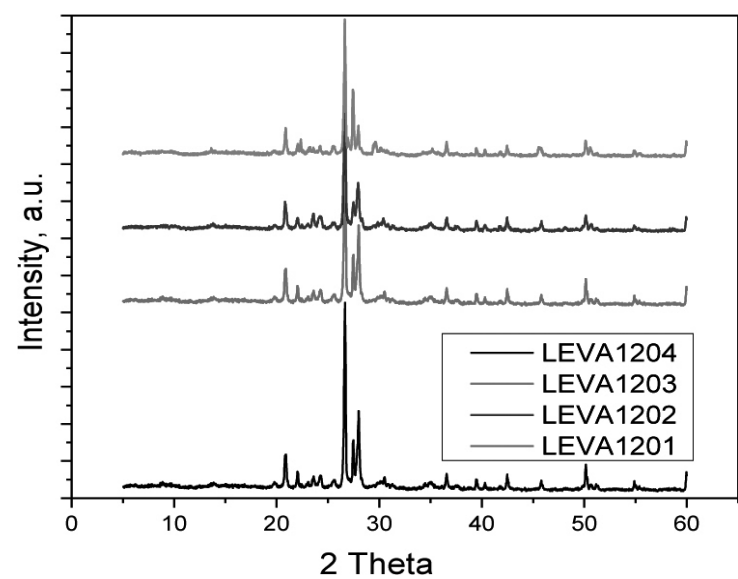

Зураг 1. LEVA1201, 1202, 1203, 1204 дээжийн рентген дифракиийн харьиуулсан спектр

ХҮснэгт 2

Дээжсид бүртгэгдсэн фазын агуулга

\begin{tabular}{|c|c|c|c|c|c|}
\hline & $\frac{\text { Quartz }}{\underline{\mathrm{SiO}}_{\underline{2}}}$ & $\frac{\text { Microcline }}{\mathbf{K A I S i}_{\mathbf{3}} \mathbf{O}_{\mathbf{8}}}$ & $\frac{\text { Albite }}{\mathbf{N a A l S i}_{3} \mathbf{O}_{8}}$ & $\frac{\text { Muscovite }}{\mathbf{K A l}_{2}\left(\mathbf{S i}_{3} \mathbf{A l}\right) \mathbf{O}_{10}(\mathbf{O H})_{2}}$ & $\begin{array}{l}\mathrm{Mg} \text { rich Kutnohorite } \\
\mathrm{Ca}(\mathrm{Mn}, \mathrm{Mg})\left(\mathrm{CO}_{3}\right)_{2}\end{array}$ \\
\hline LEVA1201 & $\underline{36.8}$ & 37.9 & 16.9 & $\underline{15.1}$ & \\
\hline$\overline{\text { LEVA1202 }}$ & $\overline{38.1}$ & 16.2 & 26.9 & 8.8 & 9.2 \\
\hline LEVA1203 & $\underline{\underline{20.6}}$ & 11.5 & 12.4 & 88 & $\underline{54.2}$ \\
\hline$\overline{\text { LEVA1204 }}$ & $\overline{43.9}$ & 16.4 & 30.8 & & \\
\hline
\end{tabular}

Материалыг(Solongo, 2006)-дөгүүлсэн

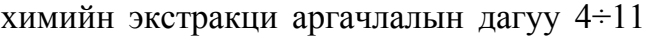
мкм-ийн хэмжээстэй полиминерал болон $212 \div 250$ мкм-ийн кварц $\left(\mathrm{SiO}_{2}\right)$ мөхлөгт кристаллыг гарган авч эдгээр материалд тохирсон pIRIR болон SGL аргачлалыг ашиглав (Хүснэгт 1).

LEVA1201, LEVA1202, LEVA1203, LEVA1204 дээжийн нарийн хэмжээст материал болох $4 \div 11 \mu \mathrm{m}$ полиминерал материал нь кварц, калийн жонш, натрийн албит г.м. эрдсээс бүрдэж буй тул зөвхөн жоншийг тусгаарлан бүртгэх зорилгоор нил улаан туяаны гэрлийн лазераaр (IR, $870 \mathrm{Hm}, 145 \mathrm{~mW} / \mathrm{cm}^{2}$ ) $50^{\circ} \mathrm{C}$-д болон $225^{\circ} \mathrm{C}$-д хослуулан өдөөх pIR-IR шинэ арга зүйг туршин явуулав. Харин $212 \div 250$ мкмийн кварцын кристаллыг ногоон лазерын тусламжтай фото өдөөлтийн люминесценцийн хэмжилтийг явуулав. Фото өдөөлтийн туршилтын хэмжилтийг ХБНГУ-ын Макс-Планк-Институтийн Люминесценцийн лабораторид Risø TL-DA-20 болон single grain attachment төхөөрөмжийг ашиглан гүйцэтгэв.

\section{ЛЮМИНЕСЦЕНЦИЙН ХЭМЖИЛТИЙН ҮР ДУН}

\section{1. Нил улаан гэрлийн люминесценци pIRIR}

Полиминерал материалаас зөвхөн жоншны люминесценцийг $50^{\circ} \mathrm{C}$-д нил улаан гэрлээр өдөөж улмаар өндөр температурын мужид нил улаан гэрлээр өдөөх арга зүй post
IR-IR-г(J.P.Buylaert,2012)туршихзорилгоор урьд өмнө өөр аргаар туршин судласан дээжийг ахин ашиглан харьцуулав. Бид өмнөх туршилтаар Бороогийн суурингаас 
олдсон ваар Нu3-2 дээжийг post IR-OSL буюу полиминералаас зөвхөн кварцын люминесценцийг бүртгэх арга зүйг туршин явуулж De=7.13Gy гэсэн үр дүн гарган авсан (Saran Solongo et al., 2013) ба кварцын люминесценцийн гол компонент үгүйтэй холбоотой он цаг хойшлох магадлалтай байсан. Туршилтын Hu3-2 дээжийг post
IR-IR-ийн аргаap $\mathrm{PH}=240^{\circ} \mathrm{C}, \quad$ pIRIR-ийн өдөөлтийн температур $210^{\circ} \mathrm{C}$ байхаар сонгон авч хэмжив. Туршилтын 5 дэд дээжид хуримтлагдсан тун $\quad \mathrm{De}_{\mathrm{IR} 50}=5.97 \pm 0.52 \mathrm{~Gy}$, $\mathrm{De}_{\mathrm{pIRIR}}=7.56 \pm 0.73 \mathrm{~Gy}$ байсан ба post-IR-OSLийн хэмжилтийн үр дүнтэй хэмжилтийн алдааны хүрээнд дүйцэж байсан хэдий ч 100 жилээр урагш үр дүнд хүрэв.
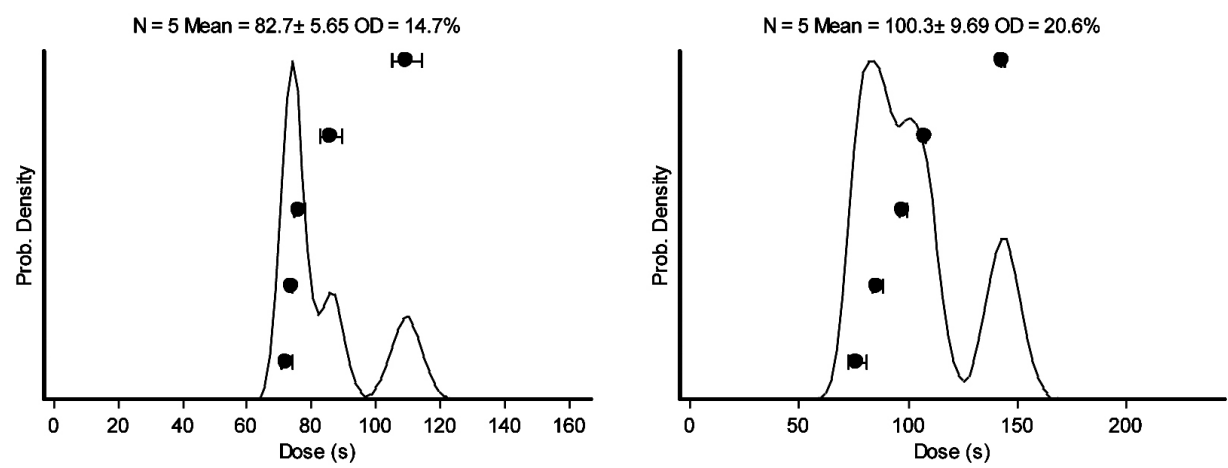

Зураг 2. IR50 болон рIRIR210С-ийн хэмжилтийн Үр дүн. Низ-2 дээжид хуримтласан тун

$$
D e_{\text {IR } 50}=5.97 \pm 0.52 G y, D e_{\text {pIRIR }}=7.56 \pm 0.73 G y
$$

LEVA1201 дээжид хийсэн люминесценцийн туршилтаар $\mathrm{T}_{\mathrm{PH}}=150^{\circ} \mathrm{C}$-д халааж инфра улаан гэрлээр хослуулан өдөөх аргаap (IR50 $\left.{ }^{\circ} \mathrm{C} / \mathrm{pIRIR} 225^{\circ} \mathrm{C}\right)$ хэмжсэн SAR протоколын (Wintle and Murray, 2006) хэмжилтийн үр дүнг үзүүлсэн ба хэмжилтийн муруйд дөхүүлэлт хийн параметрыг тогтоож, IR50 болон pIRIR225 -ийн тунгийн хамаарлыг олж хуримтлагдсан тун De ${ }_{\text {IR } 50}=8.51 \pm 0.10 \mathrm{~Gy}$ болон $\mathrm{De}$ pIRIR $=8.74 \pm 0.10 \mathrm{~Gy}-\Gamma$ тогтоов. Туршилтын температурыг $\mathrm{T}_{\mathrm{PH}}=250^{\circ} \mathrm{C}$ болгон өөрлөхөд туршилтын люминесценцийн эрчим буурч, нөгөөтэйгүур дөхүүлэлт хийж олсон параметр хоёр компонент буйг илрүүлэв. Энд хоёр дахь компонентын эрчим IR50 болон pIRIR225-ийн хэмжилтэнд ижил болж буйг ажиглав. $\mathrm{T}_{\mathrm{PH}}=250^{\circ} \mathrm{C}$-д $\operatorname{IR} 50^{\circ} \mathrm{C}$ болон pIRIR $225^{\circ} \mathrm{C}$ өдөөлтийг хослуулан явуулсан хэмжилтээр IR50 болон pIRIR225 -ийн тунгийн хамаарлыг олж хуримтлагдсан тун $\quad \mathrm{De}_{\mathrm{IR} 50}=10.08 \pm 0.48 \mathrm{~Gy}$ болон $\mathrm{De}$ pIRIR $=10.81 \pm 0.57 \mathrm{~Gy}$ болохыг тогтоов. 


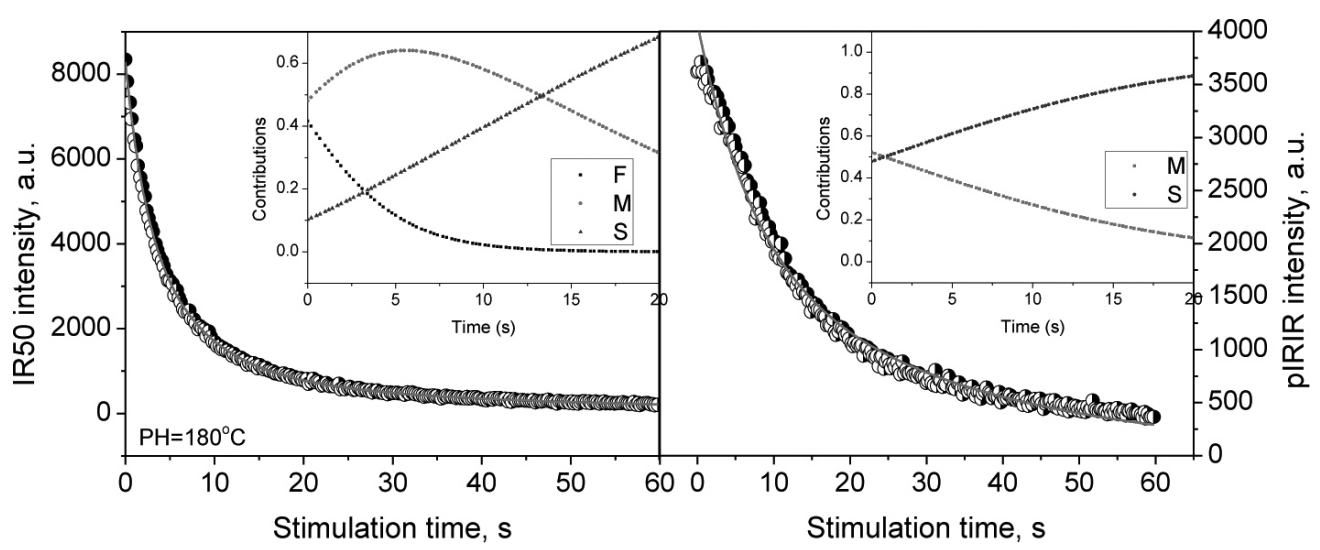

3ураг 3. IR50, pIRIR225-ийн люминесиениийн туршилтын муруй. Туршилтын температур $T_{P H}=150^{\circ} \mathrm{C}$
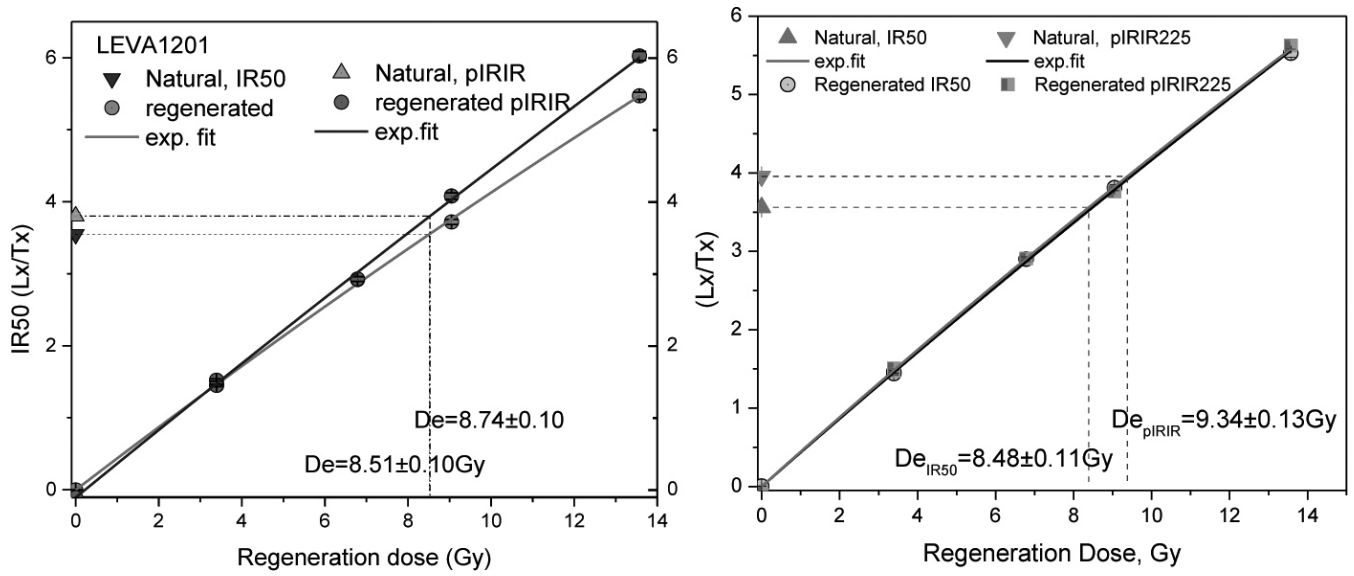

Зураг 4. Инфра улаан гэрлийн өдөөлтийг хослуулан хэмжиж тогтоосон тунгийн хамаарал. LEVA1201 дэээид хуримтлагдсан тун De $e_{\text {IRSO }}=8.51 \pm 0.10 \mathrm{~Gy} ;$ De ${ }_{\text {pIRIR }}=8.74 \pm 0.10 G y . T_{P H}=150 \mathrm{C}$
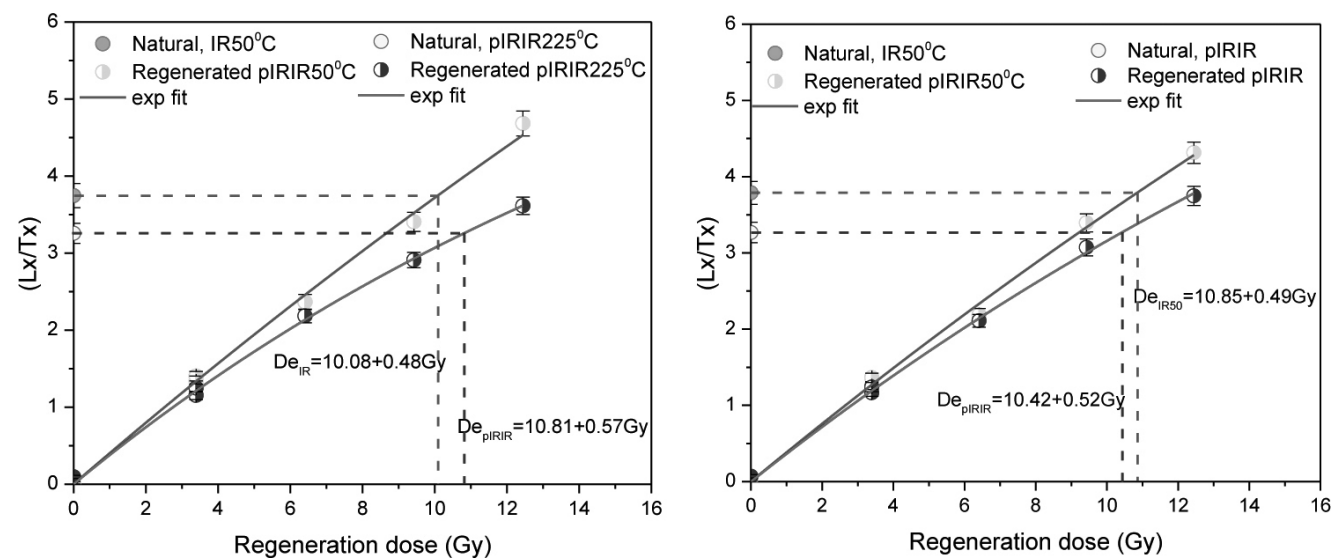

Зураг 5. Инфра улаан гэрлийн өдөөлтийг хослуулан хэмжиж тогтоосон тунгийн хамаарал. LEVA1201. D $e_{\text {IRSO }}=10.08 \pm 0.48 G y, D e_{\text {pIRIR }}=10.81 \pm 0.57 G y . T_{P H}=250^{\circ} \mathrm{C}$ 
ХУснэгт 3

IR50, pIRIR225-ийн люминесиенцийн туриилтын муруйн дөхҮүлэлтийн

\begin{tabular}{|l|c|c|c|c|}
\hline & Component & Magnitude $\left(\mathrm{cm}^{-3}\right)$ & $\begin{array}{c}\text { Detrapping } \\
\text { rate } f_{i}\left(\mathrm{~s}^{-1}\right)\end{array}$ & $\begin{array}{c}\text { Photoionization cross- } \\
\text { section } \sigma\left(10^{-19} \mathrm{~cm}^{2}\right)\end{array}$ \\
\hline \multirow{2}{*}{$\begin{array}{l}\text { LEVA1201,D39 } \\
\text { PH250-IR50 }\end{array}$} & 2 & $1945 \pm 82$ & $0.20 \pm 0.007$ & $3.42 \pm 0.12$ \\
\cline { 2 - 5 } $\begin{array}{l}\text { LEVA1201,D39 } \\
\text { pIRIR225 }\end{array}$ & 3 & $6266 \pm 222$ & $0.01 \pm 0.001$ & $0.297 \pm 0.0248$ \\
\hline \multirow{2}{*}{$\begin{array}{l}\text { Leva1201, } \\
\text { PH150, IR50 }\end{array}$} & 3 & $1721 \pm 105$ & $0.16 \pm 0.0078$ & $2.77 \pm 0.132$ \\
\cline { 2 - 5 } & 2 & $3646 \pm 329$ & $0.01 \pm 0.001$ & $0.251 \pm 0.0255$ \\
\hline \multirow{2}{*}{$\begin{array}{l}\text { Leva1201, } \\
\text { PH150,pIRIR225 }\end{array}$} & 2 & $24202 \pm 708$ & $0.43 \pm 0.04$ & $7.34 \pm 0.698$ \\
\cline { 2 - 5 } & 3 & $36742 \pm 482$ & $0.02 \pm 0.008$ & $2.26 \pm 0.14$ \\
\hline
\end{tabular}

Хэмжилтийн муруйд $1,2,3$ ажиглагдаж буй компонент $225^{\circ} \mathrm{C}$-д экспонент функциэр дөхүүлэлт хийж 2 үгүй болж байв. IR50 болон pIRIR225-д компонент тодорхойлогдож байв. Харин тулгуурлан тооцоолсон тунгийн утга нам температурын халаалт $\mathrm{T}_{\mathrm{PH}}=150 \mathrm{C}$-д ойролцоо болж байгаa нь харагдав.
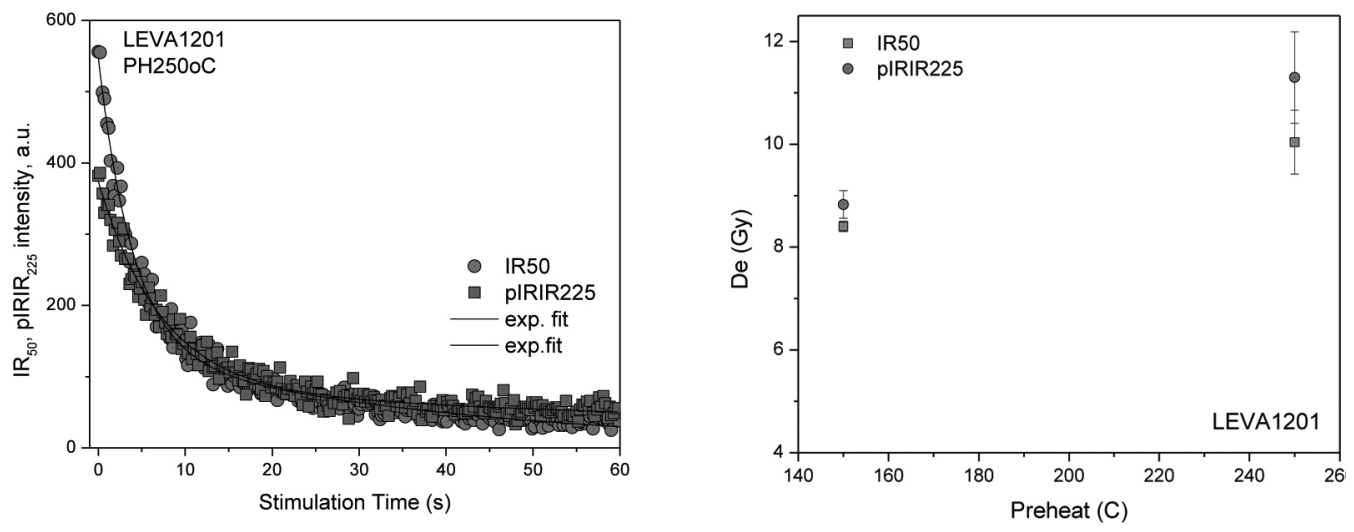

3ypaz 6. IR болон pIRIR люминесиенцийн туршилтын муруй. $T=250 C$

LEVA1202 болон LEVA1203 дээжийн IRболонрIRIRлюминесценцийнтуршилтын Yp дүнг товч нэгтгэхэд: люминесценцийн муруйн эрчим маш өндөр, ялангуяа 50С-д өдөөлтийн люминесценцийн эрчим өндөр температурынхаас 3 дахин их байв. Лабораторийн тун 3.35, 6.71, 8.91, 13.41Gy өгч люминесценцийн эрчим болон тунгийн хамаарлын муруйг босгож байгалын тунг тогтоох боломжгүй ба цэнэг алдах процесс дутуу явагдсан дээж байх магадлалтай тул кварцын кристаллын хэмжилт хийж уг таамаглалыг шалгах хэрэгтэй болов. 


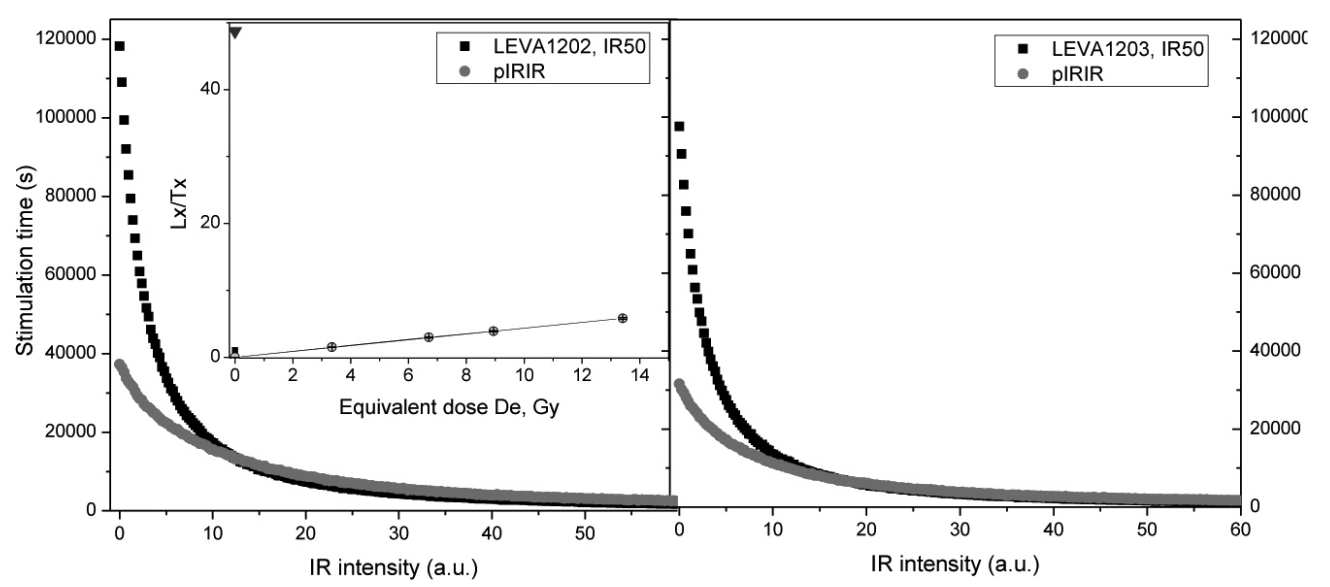

Зураг 7. LEVA1202 болон LEVA1203 дээжийн IR болон рIRIR люминесиенцийн туршилтын муруй. $L x / T x$ болон тунгийн хамаарал.

\section{2. Кварцын кристаллын люминесценци (Single grain OSL)}

$212 \div 250$ мкм-ийн ширхэгтэй кварцын кристаллыг ногоон гэрлийн лазераар өдөөж кристаллын ширхэг бүрийн люминесценцийн сигналыг бүртгэх нь тунгийн тархалтын талаар мэдээлэл өгөх боломжийг олгодог. Бид энэ ажилд зөвхөн цэнэгээ бүрэн алдсан болон цэнэгээ бүрэн бус алдсан тохиолдлыг шалгахыг зорив. Бета тунгийн гетероген түгээлт хэрхэн нөлөөлж буйг болон түгээлтийн функцийн анализ г.м. энд судлаагүй болно.

Нийт хэмжсэн үр дүнг 8-р зурагд нэгтгэн харуулсан ба тунгийн хэмжилтийн алдааг $<20 \%$ байх, рекупераци $<5 \%$ байх гэсэн шалгуур сонгон авсан дээжийн 400 кристаллыг SG-ийн люминесценцийн аргаар хэмжин дээрхи шалгуурт нийцэх 135 кристаллын тунгийн тархалтыг зураг 8а)-д гистограмм болон радиаль плотоор (баруун гар талд) дүрслэн харуулав. Тунгийн нормаль тархалт кварцын кристалл керамикийг шатаах үед цэнэгээ бүрэн алдаж цацрагийн тунг хуримтлуулах процесс эхэлснийг гэрчилнэ. Хуримтлагдсан тун $\mathrm{De}=9.48 \pm 0.08 \mathrm{~Gy} ; \sigma_{\mathrm{OD}}=6.83 \%$ байна.

Зураг 8b) - д хөрсний дээж LEVA1202ийн 400 ширхэг кристаллыг хэмжихэд зөвхөн 82 нь дээрх шалгуурт нийцсэн ба тунгийн тархалтын гистограммыг үзүүлэв. Хуримтлагдсан тун $\quad \mathrm{De}=13.83 \pm 2.10 \mathrm{~Gy}$; $\sigma_{\mathrm{OD}}=95.9 \%$ байна. Хамгийн бага тунг тооцох загварыг ашиглан De=5.73 $\pm 0.08 \mathrm{~Gy}$ гэсэн утгыг олов.

Харин LEVA1203 дээжийн 100 кристаллаас 58-д тулгуурлан гистограммыг зураг 8c)-д үзүүлсэн ба энэ нь цэнэг бүрэн бус алдсан дээж мөн болохыг харж болно. Энд 2 популяци ажиглагдсан ба бага дозтой популяци 9.34 \pm 1.20 Gy буюу бүрэн цэнэг алдсан муж ба хоёр дахь популяци нь хөрсний седиментацийн үед хамаарч байна.

Зураг 86 болон 8c -г харьцуулан анализ хийж, ялангуяа гистограмм болон харгалзах радиаль плотыг харьцуулан шинжлэхэд LEVA1202 нь цэнэгээ бүрэн бус алдсан гэхээс илүүтэй ахин холилдсон байна гэж үзэв. Хамгийн бага дозыг 5.73 Gy-д харгалзаж байна. Энэ нь гадны популяцитай холилдсон үед харгалзах ба булш тоногдсон он цагийг (588 $\pm 70 \mathrm{AD})$-онд харгалзах боломжтой гэж үзэв. 

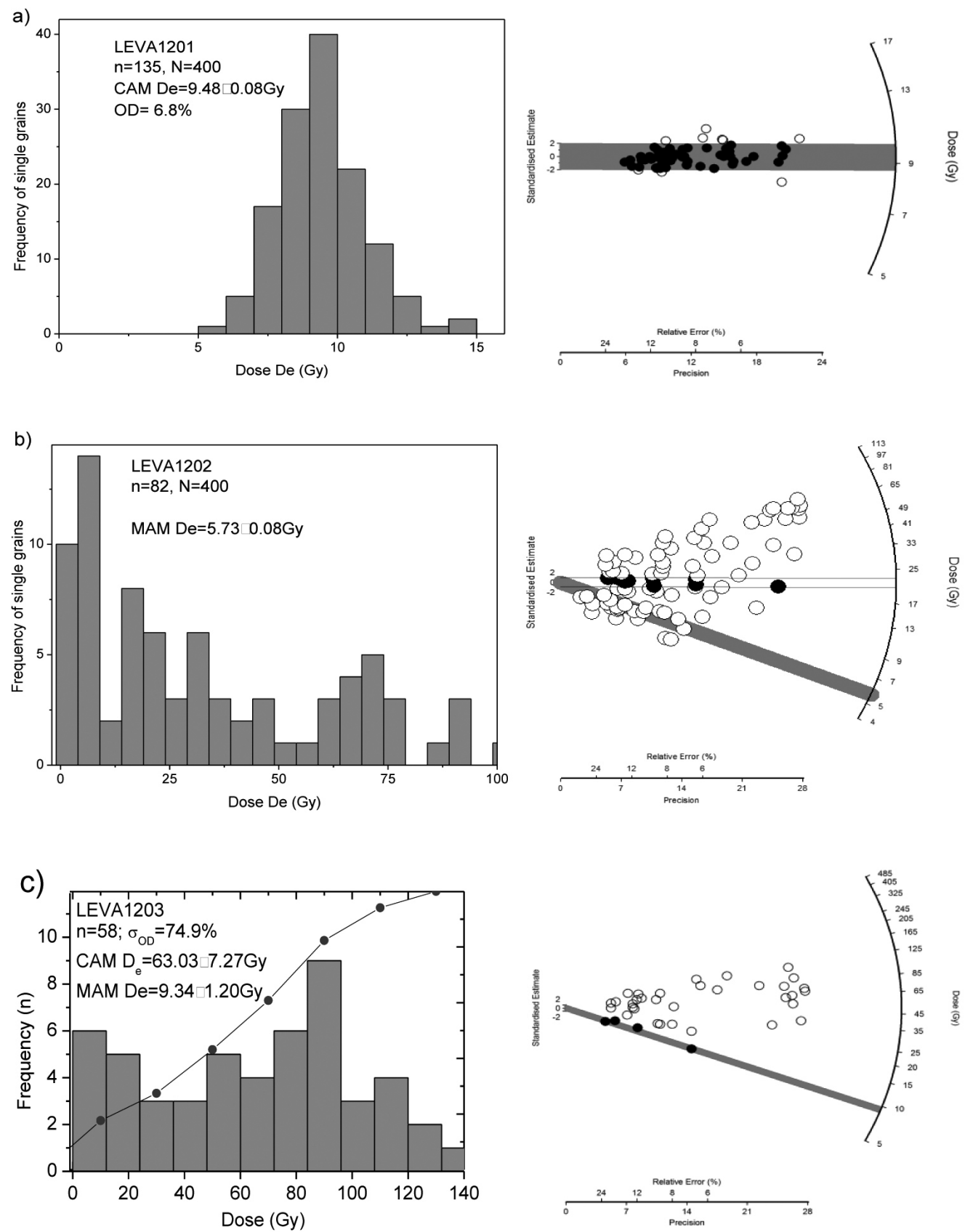

Зураг 8. Квариын кристалльн тунгийн тархалтын гистограмм болон радиаль плот. LEVA1201, LEVA1202, LEVA1203. 
Нийт хуримтлагдсан цуачрагийн тун, цุацрагийн тун хуримтлагдах жилийн дундаж хурд, он цуаг тогтоосон дүн

\begin{tabular}{|c|c|c|c|}
\hline Дээж & $\mathbf{D e}, \mathbf{G y} / \mathbf{a p r a}$ & $\mathbf{D r}_{\text {eff }}$ ( $\left.\mathbf{m G y} / \mathbf{a}\right)$ & $\mathbf{O H}$ \\
\hline \multirow{3}{*}{ LEVA-1201 } & $10.15 \pm 0.15$ ( IR50) & \multirow{2}{*}{$5.09 \pm 0.17$} & $3 \pm 75 \mathrm{BC}$ \\
\cline { 2 - 2 } & $11.28 \pm 0.30$ (pIRIR) & & $203 \pm 95 \mathrm{BC}$ \\
\cline { 2 - 2 } & $8.40 \pm 0.10$ (IR50) & \multirow{2}{*}{$5.09 \pm 0.17$} & $363 \pm 60 \mathrm{AD}$ \\
\cline { 2 - 2 } & $8.83 \pm 0.27$ (pIRIR) & & $280 \pm 83 \mathrm{AD}$ \\
\cline { 2 - 2 } & $9.48 \pm 0.08$ (SGL) & $4.291 \pm 0.154$ & $197 \pm 80 \mathrm{BC}$ \\
\hline LEVA-1202 & $5.73 \pm 0.08 \mathrm{~Gy}$ (SGL) & $4.02 \pm 0.19$ & $588 \pm 70 \mathrm{AD}$ \\
\hline LEVA-1203 & $9.34 \pm 1.20$ (SGL) & $4.31 \pm 0.18$ & $205 \pm 170 \mathrm{BC}$ \\
\hline
\end{tabular}

Люминесценцийн судалгааны салшгүй нэг хэсэг болох орчны цацрагийн тун хуримтлагдах хурдыг тодорхойлох хэсэгт цогч системийг авч судалсан ба альфа болон бета цацрагийн утгыг шавар олдворын нейтрон активацийн хэмжилтээр, харин орчны гамма цацрагийн утгыг эргэн тойронд буй хөрсний гамма спектрометрийн туршилтаар тодорхойлсон (Хүснэгт 1-ийг үз). Бета тоолуурын болон гамма

\section{Дүгнэлт}

Нарийн ширхэгтэй полиминералыг инфра улаан гэрлийн люминесценцийн (pIRIR $50^{\circ} \mathrm{C} / 225^{\circ} \mathrm{C}$ ) туршилт явуулж хэмжилтийн үр дүнг 212 мкм-ийн кварцын кристаллыг ногоон гэрлийн люминесценцийн үр дүнтэй харьцуулан судлав. Нам температурт буюу $\mathrm{T}_{\mathrm{PH}}=150^{\circ} \mathrm{C}$ -д явуулсан инфра улаан гэрлийн люминесценцийн хэмжилтээр калийн жоншийн тогтвортой бус гүн түвшинг өдөөж, харин өндөр температурт явуулсан люминесценцийн хэмжилтийн $\mathrm{yp}$ дүн тогтвортой гүн түвшинг өдөөсөн нь туршилтын муруйд хийсэн дөхүүлэлт харуулав. Цаашид өндөр температур $320^{\circ} \mathrm{C}$-ийн мужид туршилтыг явуулах шаардлагатай ба цэнэг шилжилтийн үзэгдэл явагдаж буй эсэхийг, хэрэв дулааны улмаас цэнэг шилжилт явагдаж буй спектрометрийн хэмжилтээр тодорхойлсон бета цацрагийн утга хоорондоо ялгаатай байгааг ялангуяа хөрсний хэмжилтэнд илэрхий байгаa хүснэгтээс харж болно. Нийт цацрагийн агуулганд бета цацрагийн эзлэх хувь их, нөгөөтэйгүүр түүний гомоген бус байх явдал люминесценцийн үр дүнд ихээхэн нөлөөлдөг. Хөрс гадны нөлөөгөөр холилдсон байсан нь хэмжилтийн алдаанд нөлөөлсөн байх магадлалтай.

тохиолдолд түүнийг хэрхэн тооцох вэ зэрэг асуудлыг судлах хэрэгтэй. Мөн үлдэгдэл цэнэг хуримтлагдах магадлалыг бид энэ судалгаанд тогтоох цаг хугацааны боломж гараагүй цохон тэмдэглэе.

Архангайн Хашаат сумын Хутаг Уулын Оршуулгын газрын булшнаас авсан шавар ваарны хэлтэрхий ба түүнд харгалзах орчны хөрсний дээж нь люминесценцийн болон цацрагийн судалгаа явуулахад нэн тохиромжтой систем болов. pIRIR болон Single grain хэмжилтүүдийг хослуулан явуулж гарган авсан дүн нь $(203 \pm 95 B C$; $197 \pm 80$ ВС ) алдааны хүрээнд нийцэж байв. Хөрсний дээж (LEVA1202) гадны үйлчлэлээр бохирдсон буюу булш тоногдсон он цагийг 588土70AD онд харгалзах магадлалтай гэж үзэв. 


\section{Талархал}

Доктор С.Саран нь хэмжилтийг ХБНГУ-ын Лайпциг хотын Макс-Планкийн Институтын Люминесценцийн Лабораторитой хамтын ажиллагааны хүрээнд Германы Судалгааны Нийгэмлэг (DFG) - ийн грант авч хэрэгжүүлсэн болно. Хамтран ажилласан байгууллага, эрдэмтдэд талархал илэрхийлье.

\section{Ашигласан бүтээлийн жагсаалт}

- Aitken, M. (1998). An Introduction to Optical Dating - The Dating of Quaternary Sediments by the Use of Photon-Stimulated Luminescence. Oxford: Oxford Science Publications.

- Bailiff, I. (2007). Methodological developments in the luminescence dating of brick from English late-medieval and post-medieval buildings. Archaeometry, 49 , 744-9.

- Bǿtter-Jensen L., S. S. (2000). Using the OSL single-aliquot regenerative-dose protocol with quartz extracted from building materials in retrospective dosimetry. Radiation Measurements, $32,841-845$.

- J.P.Buylaert, M. A. (2012). A robust feldspar luminescence dating method for Middle and Late Pleistocene sediments. Boreas , 435-451.

- Krbetschek M.R., G. J. (1997). Spectral information from minerals relevant for luminescence dating. Radiation Measurements 27, 695-748.

- Prescott J.R., Hutton J.T. (1994). Cosmic ray contributions to dose rates for luminescence and ESR dating: Large depths and long-term time variations. Radiation Measurements 23, 497500 .

- Solongo, S. W. (2006). The dose estimation using fast and medium components in fired quartz from archaeological site Kharakhorum, Mongolia. Radiation Measurements, Vol.41, , pp. 1001-1008.

- Solongo S., Richter D., Tuguldur B., Hublin J.J. (2013). OSL and TL characteristics of fine grain quartz from Mongolian prehistoric pottery used for dating. Geochronometria. DOI 10.2478/ s13386-013-0119-4

- Саран, С. (2010). Хархорумын археологийн олдвороос гарган авсан кварцын люминесценцийн шинж чанар. ФТХ-ийн бүтээл, 1-9.

- Wintle, A.G. and Murray, A.S. (2006). A review of quartz optically stimulated luminescence characteristics and their relevance in single-aliquot regeneration dating protocols. Radiation Measurements , $369-391$. 